AL IBTIDA: JURNAL PENDIDIKAN GURU MI (2017) VOL. 4(2): 201-216

DOI: http://dx.doi.org/10.24235/al.ibtida.snj.v4i2.1770

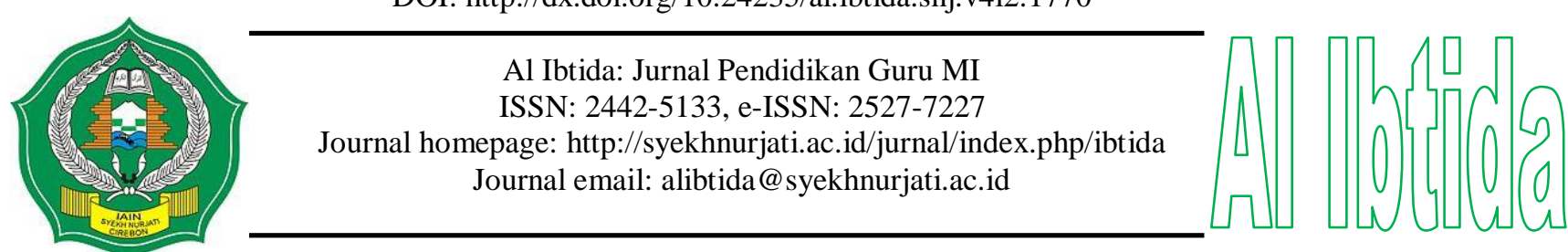

\title{
Studi Implementasi Ujian Online Menggunakan LMS Moodle pada Mahasiswa PGMI UNISKA MAB Banjarmasin
}

\author{
Hamdan Husein Batubara* \\ *Jurusan Pendidikan Guru Madrasah Ibtidaiyah, Fakultas Studi Islam, \\ Universitas Islam Kalimantan MAB Banjarmasin \\ Email: huseinbatubara@gmail.com
}

Received 05 August 2017; Received in revised form: 10 October 2017; Accepted 11 October 2017

Publish Online: 27 October 2017

\begin{abstract}
Abstrak
Penelitian ini bertujuan untuk mengkaji pelaksanaan ujian online menggunakan kuis LMS Moodle. Penelitian ini menggunakan metode campuran dengan instrumen kuesioner, wawancara, dan dokumentasi. Subjek penelitian ini adalah mahasiswa program studi Pendidikan Madrasah Ibtidaiyah Guru Pendidikan Universitas Islam Kalimantan MAB Banjarmasin. Hasil penelitian ini menemukan prosedur implementasi ujian online yang terdiri dari: mempersiapkan item soal yang akan diujikan, membuat kategori soal, membuat dan mengunggah soal ke bank soal, membuat kategori nilai, menambahkan fitur kuis, melaksanakan ujian online, mengoreksi, dan mengunduh nilai. Tingkat kepuasan responden terhadap pelaksanaan ujian online berada pada kategori baik sebesar $45 \%$, sangat baik $18 \%$, kurang baik $25 \%$, dan tidak baik $12 \%$. Hal-hal yang perlu diperhatikan sebelum pelaksanaan ujian online adalah: kondisi jaringan internet, jumlah komputer yang siap pakai, dan sosialisasi standar penyelenggaraan ujian online.
\end{abstract}

Kata kunci: ujian online, moodle, e-learning.

\begin{abstract}
This study aims to examine the implementation of online exams using quiz of LMS Moodle. This study uses a mixed method using questionnaire, interview, and documentation. The subjects of the study were students of Madrasah Ibtidaiyah Teacher Training Department of Kalimantan Islamic University MAB Banjarmasin. The results of this study found that procedure of the online exam implementation consists of: preparing items to be tested, creating question category, creating and uploading questions to question bank, creating grade category, adding quiz feature, executing online exam, correcting and downloading grades. The level of respondent satisfaction to implementation online exam is in good category of $45 \%$, very good $18 \%$, less good $25 \%$, and not good $12 \%$. Things to be considered before online exam implementation are: the condition of internet network, the number of computers ready for use, and the socialization of online exam implementation standards.
\end{abstract}

Keywords: online exam, moodle, e-learning 


\section{PENDAHULUAN}

Penilaian adalah proses pengumpulan dan pengolahan informasi untuk mengukur pencapaian hasil belajar peserta didik. Tujuan penilaian dapat ditinjau dari fungsi sumatif dan formatif. Fungsi sumatif penilaian adalah mengukur dan menilai tingkat pencapaian kompetensi peserta didik serta mendeskripsikan capaian hasil pembelajaran peserta didik, dan fungsi formatifnya adalah mendiagnostik kesulitan belajar peserta didik dalam pembelajaran, memberi petunjuk bagi pendidik dan peserta didik dalam meningkatkan mutu pembelajaran, mengetahui kekuatan dan kelemahan dalam proses pembelajaran, sehingga hasil penilaian tersebut dapat dijadikan dasar untuk pengambilan keputusan, dan perbaikan proses pembelajaran yang telah dilaksanakan (Tim Direktorat Pembinaan Sekolah Dasar Kemdikbud, 2016: 5).

Sementara itu, penilaian yang bermutu adalah salah satu tugas pendidik dan satuan pendidikan. Penilaian yang bermutu harus mengacu pada standar penilaian pendidikan, yaitu kriteria mengenai lingkup, tujuan, manfaat, prinsip, mekanisme, prosedur, dan instrumen penilaian hasil belajar peserta didik yang digunakan sebagai dasar dalam penilaian hasil belajar peserta didik.

Menanggapi era teknologi saat ini, pendidikan dituntut untuk dapat menyesuaikan diri dan memanfaatkan teknologi informasi dan komunikasi untuk memudahkan dan meningkatkan kualitas pelaksanaan pendidikan, pembelajaran dan penilaian. Keakraban masyarakat dengan berbagai produk teknologi seperti komputer, tablet, smartphone, serta tersedianya koneksi internet yang semakin murah merupakan sebuah peluang bagi dunia pendidikan dalam memanfaatkan kecanggihan teknologi agar peserta didiknya tidak gagap dalam menggunakan berbagai perangkat teknologi terbaru. Salah satu software yang dapat digunakan dalam penilaian pembelajaran yang memiliki fitur lengkap, mudah dimengerti, dan lisensinya gratis adalah $L M S$ Moodle.

Moodle, singkatan dari Modular Object-Oriented Dynamic Learning Environment adalah sebuah platform pembelajaran yang dirancang untuk memberikan pendidik, administrator dan peserta didik sebuah lingkungan berlajar berbasis website dengan berorientasi pada peserta didik dan mempertahankan prinsip-prinsip pembelajaran (social instructional pedagogy). Aplikasi ini dibuat oleh Martin Dougiamas dan telah menjadikannya sebagai aplikasi gratis yang bebas didistribusikan dan dimodifikasi di bawah ketentuan GNU (General Public License). Dibutuhkan ruangan hosting (untuk menempatkan file di website) minimal $160 \mathrm{MB}$. Server harus mendukung Apache, PHP 5.3.2, dan database MySQL atau PostgreSQL yang sesuai dengan versi Moodle yang digunakan (Kompas Tekno, 2008). 
Fitur LMS Moodle yang dapat digunakan dalam kegiatan ujian online adalah fitur quiz. Fitur quiz dapat digunakan untuk membuat berbagai bentuk soal dengan mudah, menyimpan soal tersebut dalam bank soal, dan memberikan penilaian serta umpan balik kepada peserta didik secara otomatis. Pengajar juga bisa mengamankan kuis dengan sandi, mengatur waktu tersedianya, batas waktu pengerjaan, batas waktu pengulangan dan penyajian soal secara acak atau urut. Dengan modul ini, pengajar akan lebih mudah memberikan kuis atau ujian melalui situs LMS Moodle_dan peserta didik pun bisa langsung mengerjakan kuis tersebut melalui perangkat komputer atau smartphone-nya (Prismanata, 2016).

Adapun di antara keunggulan pelaksanaan ujian online menggunakan modul quiz LMS Moodle adalah: 1) mendukung program penghematan kertas sebagai wujud peduli lingkungan, 2) menghemat biaya dan tenaga pengelola sekolah dalam mencetak dan mendistribusikan lembar soal dan lembar jawaban, 3) fitur acak otomatis soal pada sistem ujian online diharapkan dapat meminimalisir kecurangan saat ujian, 4) lebih memudahkan peserta didik dalam mengisi biodata dan menjawab soal dengan tanpa alat tulis, melainkan hanya menggunakan mouse, 5) soal dalam bentuk suara ataupun video dapat disajikan dengan baik dan utuh dalam aplikasi soal online, dan 6) hasil ujian online yang berupa soal objektif seperti pilihan ganda atau benar salah dapat diketahui hasilnya dengan cepat dan guru terbantu dalam menganalisis kemampuan peserta didik pada setiap butir soal.

Adapun beberapa potensi masalah yang mungkin terjadi pada pelaksanaan ujian online adalah: 1) jumlah laptop/ PC/ smartphone yang tersedia tidak memadai atau kurang dari jumlah peserta didik, 2) jaringan internet yang digunakan tidak stabil, 3) jadwal ujian yang bergelombang berpotensi pada bocornya soal dari peserta gelombang pertama kepada peserta yang berada pada gelombang kedua, ketiga, dan seterusnya, dan 4) aliran listrik menjadi syarat utama dalam mengerjakan ujian.

Hasil penelitian Muhammad Rizal Fauzi tentang penggunaan Google Form sebagai alat evaluasi pembelajaran pada mata pelajaran Bahasa Indonesia, mengungkapkan bahwa penggunaan Google Form dalam kegiatan evaluasi pembelajaran memberikan dampak dan manfaat baik dari aspek efektif, efisiensi, daya tarik dan desain tampilan. Bagi guru, sangat terbantu dengan adanya Google Form baik dari segi biaya, waktu, dan tenaga. Bagi siswa sendiri menjadi lebih tertarik, antusias, aktif dan tidak menjadi hal yang negatif untuk menghadapi ujian di SMP Negeri 1 Lembang (Fauzi, 2017).

Berdasarkan latar belakang di atas, tujuan penelitian ini adalah mengkaji implementasi ujian online menggunakan LMS Moodle, yang meliputi: perancangan halaman kuis LMS Moodle, pelaksanaan ujian online, dan persepsi responden terhadap penyelenggaraan ujian online menggunakan LMS Moodle. 


\section{METODE PENELITIAN}

Penelitian ini merupakan penelitian kuantitatif, yaitu suatu pendekatan penelitian yang secara primer menggunakan paradigma positivistik untuk mengembangkan ilmu pengetahuan dan menggunakan strategi penelitian seperti kegiatan survei yang memerlukan data statistik (Emzir, 2008: 28).

Penelitian ini juga menggunakan metode analisis deskriptif dengan menyebarkan kuesioner untuk menggali informasi dari responden penelitian, yaitu mahasiswa program studi Pendidikan Guru Madrasah Ibtidaiyah UNISKA MAB. Prosedur penelitiannya terdiri dari: 1) persiapan dan kajian literatur, 2 mengembangkan instrumen penelitian, 3) penerapan ujian online, dan 4) melakukan kajian dan analisis data.

Subjek penelitian ini adalah seluruh mahasiswa program studi PGMI UNISKA Muhammad Arsyad Al Banjari yang mengikuti ujian online. Data respon mahasiswa terhadap penyelenggaraan ujian online diperoleh dengan memberikan angket kepada seluruh responden melalui sebuah laman website. Kuisioner online tersebut dibuka mulai tanggal 2 Juni hingga dengan 8 Juni 2017 dengan harapan cukup banyak responden yang berpartisipasi dalam penelitian ini. Teknik pengambilan sampel dilakukan dengan pendekatan kasus dan purposive sampling, yakni: jumlah sampel penelitian ini adalah sebesar jumlah kuisioner yang diisi oleh responden pada laman web yang disediakan (Siregar, 2013: 33).

Instrumen yang digunakan dalam penelitian ini adalah angket, wawancara, dan studi dokumentasi. Jenis angket atau kuisioner yang digunakan pada penelitian ini adalah kuesioner terstruktur (Closed Quistionaire), yaitu kuisioner yang alternatif jawabannya telah- disediakan menggunakan skala likert. Aspek-aspek yang ditanyakan dalam angket ini adalah: gambaran tentang kondisi responden, persepsi responden tentang penggunaan kuis LMS Moodle sebagai media ujian online, dan kendala yang dialami responden dalam mengikuti ujian online menggunakan LMS Moodle. Pilihan jawaban angket ini terdiri dari 4 pilihan jawaban, yaitu: $4=$ Sangat setuju, 3= Setuju, 2=Kurang setuju, 1 = Sangat Tidak Setuju (Siregar, 2013: 33). Adapun jenis wawancara yang digunakan adalah wawancara terbuka untuk mendapatkan data tentang tanggapan pengguna terhadap penerapan ujian online. Adapun studi dokumentasi digunakan untuk menghimpun data tentang materi ujian online, prosedur pembuatan halaman ujian online, dan data pendukung kegiatan penelitian.

Alat ukur yang digunakan dalam penelitian ini telah dianalisis kualitas isinya dan diuji cobakan terlebih dahulu pada beberapa calon responden guna mengetahui validitas dan reabilitas angket. Analisis validitas dilakukan menggunakan rumus korelasi Product Moment dan analisis 
realibilitas menggunakan teknik Alpha Cronbach yang terdapat pada aplikasi SPSS for Windows Release 16.

Analisis data penelitian ini terbagi dua, yaitu: data kuantitatif dianilisis berdasarkan klasifikasi jawaban mahasiswa pada angket berdasarkan item pernyataan dan berdasarkan pilihan jawaban angket. Pilihan jawaban responden yang berbentuk skala sikap kemudian dikonversi ke dalam bentuk skala tingkat kualitas, yaitu: pernyataan sangat setuju, setuju, kurang setuju, dan tidak setuju diubah menjadi sangat baik, baik, kurang baik, dan tidak baik. Sementara untuk jenis data kualitatif dianalisis pada proses pengumpulan data, reduksi data, paparan data, dan penarikan simpulan.

\section{HASIL DAN PEMBAHASAN}

\section{A. Prosedur Pembuatan Ujian Online Menggunakan LMS Moodle}

Lembar soal ujian online menggunakan kuis LMS Moodle sebenarnya hampir sama dengan lembar ujian pada umumnya. Perbedaannya adalah terletak pada fasilitasnya yang dapat diakses secara online sehingga data berupa hasil jawaban peserta didik dapat lebih cepat dan mudah dianalisis oleh guru.

Adapun tahapan perancangan ujian online menggunakan kuis LMS Moodle adalah sebagai berikut:

1. Membuat Kategori Soal

Membuat kategori soal bertujuan untuk mengelompokkan soal-soal pada Bank soal sehingga soal-soal tersebut tersusun rapi dalam bank soal. Adapun cara membuat kategori soal adalah sebagai berikut:

a. Masuk ke halaman mata pelajaran menggunakan akun pengajar

b. Klik Course Administration pada blok Administration

c. Klik menu Question Bank

d. klik menu Categories, maka akan tampil halaman kategori soal.

e. Pada halaman kategori soal, buat kategori baru dengan cara: klik kolom Parent category untuk memilih induk kategori, ketik nama kategori pada kolom Name, ketik informasi tentang kategori pada kolom Category info, lalu tekan tombol Add category

Kategori yang berhasil dibuat akan tampil di atas menu Add category. Kategori yang telah dibuat masih dapat diubah dengan mengklik ikon gerinda ( dihapus dengan mengklik ikon silang $(\boldsymbol{X})$ yang terdapat di bawah nama kategorinya. 
2. Membuat dan Mengunggah Soal pada Bank Soal

Cara membuat dan mengunggah soal atau item pertanyaan ke bank soal dapat dilakukan dengan dua cara, yaitu dengan membuat soal langsung pada bank soal dan membuat soal-soal pada Microsoft Word lalu mengimpornya ke bank soal.

a. Membuat soal langsung pada Bank Soal

Masuk ke halaman mata pelajaran > klik Course Administration pada blok Administration > klik Question Bank > klik Questions, maka akan tampil halaman bank soal. Pada halaman tersebut, pilih kategori penyimpanan soal yang akan dibuat $>$ kemudian klik tombol Create a new question. Maka akan tampil menu pop up yang menampilkan berbagai jenis soal yang tersedia atau bisa dipilih. Seperti: Multiple choice (pilihan ganda), True/False (benar salah), Matching (menjodohkan), Short answer (jawaban teks pendek), Essay (uraian), Drag and drop into text (mengisi kata yang hilang dengan mendrag beberapa pilihan kata ke kolom kata yang hilang tersebut), dan lain sebagainya.

Misalnya, soal pilihan ganda dapat dibuat dengan cara:

1) Klik pilihan Multiple choice, lalu tekan tombol Add, maka akan tampil halaman Adding a Multiple choice question

2) Klik tulisan Expand all pada bagian kanan atas halaman untuk menampilkan semua isi pengaturan soal pilihan ganda.

3) Isi halaman pengaturan soal pilihan ganda dengan cara:

a) Klik kolom Category untuk memilih kategori penyimpanan item pertanyaan

b) Ketik nama judul soal pada kolom Question name (wajib diisi)

c) Ketik kalimat soal pada kolom Question text (wajib diisi)

d) Ketik kalimat umpan balik pada kolom General feedback, misalnya: terimakasih!, lanjut!.

e) Gunakan menu One or multiple answers? untuk mengatur apakah responden hanya boleh memilih satu jawaban (One answer only) atau boleh lebih dari satu jawaban (Multiple answer allowed)

f) Centang menu Shuffle the choices? jika ingin mengaktifkan fitur pengacakan pilihan jawaban

g) Gunakan menu Number the choices? untuk memilih jenis penomoran pilihan jawaban

h) Gunakan menu Answer untuk memasukkan pilihan jawaban. Misalnya ketik pilah jawaban pada kolom choice 1, choice 2, dan selanjutnya, kemudian klik 
menu grade untuk memilih bobot skor soal. Pilihan bobotnya adalah 5\% sd $100 \%$

i) Gunakan kolom Feedback untuk mengetikkan kalimat singkat yang akan ditampilkan pada saat responden memilih pilihan jawaban tersebut

j) Pilihan jawaban yang tersedia secara default adalah 5 pilihan. Oleh karena itu, jika pilihan jawaban yang akan dimasukkan kurang dari lima pilihan jawaban, pengajar boleh mengosongkan sisanya. Sementara jika pengajar ingin menambahkan pilihan jawaban lain sehingga lebih dari lima maka dapat dilakukan dengan cara: klik tombol Blank for 3 more choices.

k) Gunakan menu Combined feedback untuk mengatur isi feedback berdasarkan benar-salahnya jawaban peserta didik. Misalnya, ketik kalimat selamat pada kolom For any correct response dan ketik kalimat motivasi pada kolom For any partially correct response

1) Klik tombol Save changes untuk menyimpan soal.

b. Membuat soal dalam Ms.Word dan Mengimpornya ke Bank Soal

Langkah membuat item pertanyaan secara satu persatu dirasakan sebagian orang kurang efisien. Oleh Karena itu, cara lain untuk membuat item soal dapat dibuat pada dokumen Microsoft word lalu mengimpornya ke bank soal. Adapun cara membuat soal pada dokumen Ms. Word adalah sebagai berikut:

(1) Ketik soal dalam format Aiken. Perhatikan contoh berikut.

Scanner digunakan untuk...

A. Mencetak naskah

B. Menyimpan file

C. Mengetik kata

D. Memindai kertas

ANSWER: D

Istilah lain untuk memasang aplikasi komputer adalah...
A. Uninstall
B. Install
C. Open
D. Change

ANSWER: B

(2) Jika semua item soal sudah selesai diketik, simpan file Ms. Word dalam format plain text (*.txt). Caranya adalah: klik tab file, pilih menu save as maka akan 
muncul kotak dialog save as, pada jendela tersebut, ketik nama file, ubah type file (jenis file) ke format plain text, lalu tekan tombol save.

(3) Unggah file plain text ke e-learning.

Caranya adalah: masuk ke halaman mata pelajaran, klik Course administration pada blok Administration, lalu klik Question Bank, klik tombol Import, maka akan tampil halaman import. Pada halaman tersebut, klik menu File Format dan pilih Aiken format, klik menu General dan pilih kategori soal, dan klik menu Import questions from file untuk memilih file plain text (.txt) yang akan diunggah, lalu klik tombol Import, klik tombol 'Continue' maka soal yang berhasil diimpor akan tersimpan dalam bank soal.

3. Membuat Kategori Nilai

Kategorisasi nilai bertujuan untuk mengelompokkan nilai agar pengajar lebih mudah dalam mengelola nilai peserta didik berdasarkan jenis-jenis aktivitas tertentu. Oleh karena itu, pengajar perlu membuat beberapa kategori nilai yang diperlukan untuk aktivitas pembelajaran yang dinilai. Misalnya nilai untuk tugas dikelompokkan pada kategori nilai tugas, nilai ujian tengah semester dikelompokkan pada kategori nilai ujian tengah semester, Begitu untuk nilai aktivitas lain dikelompokkan pada kategori nilainya masing-masing.

Adapun cara membuat kategori nilai adalah sebagai berikut:

1) Masuk ke halaman mata pelajaran menggunakan akun pengajar

2) Klik Course administration pada blok Administration

3) Klik Gradebook setup

4) Klik tombol Add Category, maka akan tampil halaman Setup: New Category

5) Klik tulisan Expand all di bagian kanan atas halaman untuk menampilkan semua isi menu pengaturan kategori nilai

6) Ketik nama kategori pada kolom Category name

7) Pilih metode penjumlahan nilai total pada menu Aggregation, misalnya, pilih Mean of grades jika ingin nilai totalnya berupa nilai rerata

8) Pilih jenis nilai total pada menu Category total, daftar pilihannya adalah: point, scale (skala), dan text

9) Klik tombol Save Changes untuk menyimpan pengaturan kategori. 
4. Menambahkan Fitur Kuis pada Halaman Mata Pelajaran

Adapun langkah-langkah dalam menambahkan kuis pada halaman mata pelajaran e-learning adalah: Masuk ke halaman mata pelajaran > Ubah mode halaman mata pelajaran ke mode ubah dengan mengklik tombol turn editing on (hidupkan mode ubah) $>$ Klik tulisan add an activity and resource, maka akan tampil menu pop up yang menampilkan beberapa fitur yang tersedia pada e-learning. Klik ikon Quiz pada menu tersebut, dan klik tombol Add, maka akan tampil halaman pengaturan Quiz.

Selanjutnya, klik tulisan Expand all untuk menampilkan semua isi menu pengaturan. Adapun cara mengisi menu pengaturan tersebut adalah:

1) Menu General, untuk memberi judul kuis dan kolom perkenalan dengan petunjuk dan aturan penggunaan kuis

2) Menu Timing, untuk mengatur waktu dibolehkannya membuka soal-soal kuis (alokasi waktu mengerjakan sebuah kuis)

3) Menu Grade,(nilai) untuk mengatur cara penilaian oleh sistem. Seperti menentukan grade category (kategori nilai), grade to pass (nilai minimum untuk lulus), attempts allowed (jumlah percobaan menjawab yang diperbolehkan), dan grade method (cara penilaian)

4) Menu Layout, untuk mengatur jumlah item soal kuis yang ditampilkan dalam satu halaman

5) Menu Question behaviour, untuk mengatur urutan pertanyaan kuis apakah diacak atau tidak

6) Menu Review option, untuk memberikan kesempatan kepada mahasiswa untuk mereview hasil jawabannya

7) Menu Tampilan, untuk mengatur tampilan kuis saat dibuka mahasiswa

8) Menu Extra restriction on attempts, untuk menambahkan password pada kuis agar tidak ada orang lain di luar ruangan atau yang tidak berhak mengikuti kuis ikut mengerjakan kuis tersebut

9) Menu Overal Feedback, untuk memberikan Feedback secara umum kepada mahasiswa menjawab seluruh soal kuis. Feedback dapat diberikan kepada mahasiswa berdasarkan prosentasi jawaban benar mahasiswa mulai dari 0\% hingga 100\%

10) Menu Restrict Access, untuk membatasi akses mahasiswa atau kelompok mahasiswa tertentu terhadap kuis tersebut

11) Tombol Simpan dan tampilkan, untuk menyimpan pengaturan kuis. 
Selanjutnya, masukkan soal-soal yang sudah tersimpan di dalam Question Bank ke quiz dengan langkah-langkah berikut:

1) Masuk ke halaman mata pelajaran menggunakan akun pengajar

2) Klik judul quiz yang telah dibuat

3) Klik tombol Edit quiz, maka akan tampil halaman editing quiz

4) Klik tulisan Add, dan pilih From Question Bank, maka tampil jendela Question bank.

5) Pada jendela Question Bank, pilih kategori soal untuk melihat isi soal, kemudian pilih soal yang akan ditambahkan ke dalam kuis dengan mencentang kotak kecilnya

6) Klik tombol Add selected questions to the quiz, maka soal-soal yang telah dipilih akan tampil pada halaman editing quiz.

Pada halaman editing quiz, pengguna juga dapat melakukan beberapa pengaturan soal, seperti: 1) mencentang shuffle untuk mengacak urutan soal pada setiap kali dibuka peserta didik, 2) mengatur urutan soal dengan mengklik ikon move ( ${ }^{\ddagger}$ ) dan menariknya ke lokasi lain, 3) mengubah materi soal dengan mengklik ikon gerinda yang berada di belakang judul soal, 4) mengubah bobot nilai dengan menekan ikon pensil pada bagian kanan soal, lalu mengetik nilainya dan mengakhirinya dengan menekan tombol ENTER.

5. Pelaksanaan Ujian Online

Langkah-langkah dalam mengerjakan soal ujian online adalah sebagai berikut.

1) Masuk ke situs $e$-learning menggunakan akun pribadi masing-masing

2) Masuk ke halaman mata pelajaran yang akan diujikan (misalnya: TIK)

3) Klik judul modul ujian (misalnya: ujian tengah semester)

\section{Ujian Tengah Semester}

4) Baca petunjuk ujian, kemudian klik tombol attempt quiz now (mencoba kuis sekarang), lalu klik tulisan "Start attempt" untuk memulai ujian.

Time limit: 40 min

Grading method: Nilai Tertinggi

Mencoba kuis sekarang

Jika ujian online diproteksi menggunakan sandi, maka masukkan password kuis yang diberikan oleh pengelola atau guru.

Adapun tampilan halaman ujian online menggunakan kuis LMS Moodle adalah sebagai berikut. 


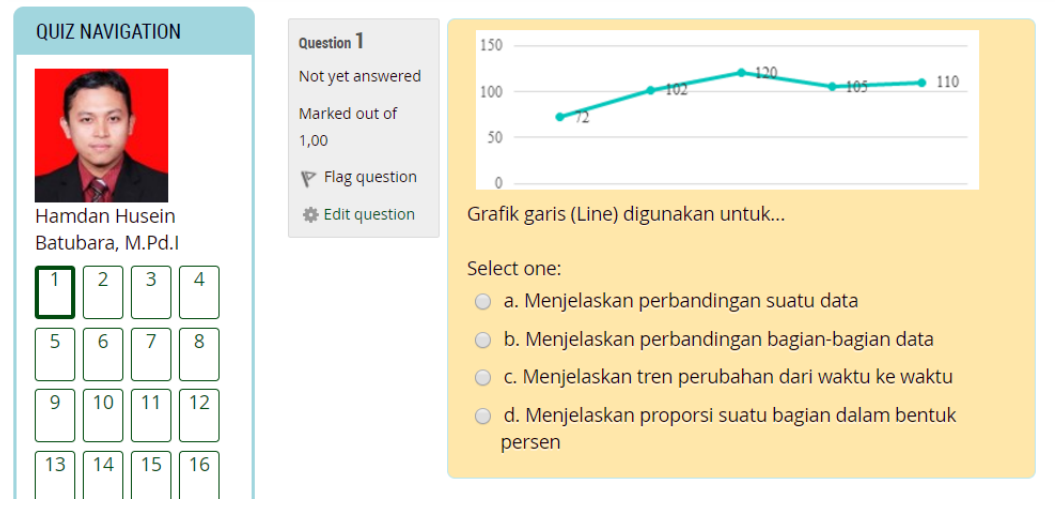

5) Akhiri kuis dengan mengklik tulisan finish attempt... pada bagian bawah blok quiz navigation.

6. Mengoreksi dan Mengunduh Nilai

Adapun langkah-langkah mengoreksi dan men gunduh nilai pada LMS Moodle adalah sebagai berikut:

1) Masuk ke situs e-learning menggunakan akun pengajar

2) Masuk ke halaman mata pelajaran

3) Klik menu "Course administration" pada blok Administration

4) Klik menu "Grades" (Nilai), maka akan tampil halaman "Grader Report" yang menampilkan seluruh nilai peserta didik.

5) Selanjutnya Pengajar dapat mengubah nilai peserta didik dengan mengklik tombol edit.

6) Untuk mengunduh nilai, pengajar harus mengklik menu drop down yang berada pada bagian atas halaman, lalu pilih "Excel spreadsheet", maka akan tampil halaman "Export to Excel spreadsheet".

7) Pada halaman "Export to Excel spreadsheet", centang komponen nilai yang akan diunduh, lalu klik tombol "Download", maka file Excel yang berisi seluruh nilai dan identitas peserta didik akan tersimpan ke dalam komputer.

\section{B. Gambaran Responden}

Responden yang mengisi angket berjumlah 35 mahasiswa dari program studi PGMI. Adapun respon mereka terhadap pelaksanaan ujian online adalah: 1) 70\% responden menyatakan bahwa mereka menggunakan internet lebih dari lima kali dalam seminggu, sedangkan sisanya 30\% menyatakan bahwa mereka mengakses internet rata-rata lima kali dalam seminggu. Seluruh responden juga menyatakan bahwa mereka telah memiliki email. Adapun hal-hal yang paling sering dilakukan mahasiswa saat mengakses internet adalah: 90\% menyatakan mereka menggunakan internet untuk mengakses media sosial dan sumber belajar (referensi), $80 \%$ responden menggunakan internet untuk chating, dan $70 \%$ responden 
menggunakan internet untuk mengirim tugas. Namun untuk kegiatan ujian online, responden mengakui bahwa mereka baru pertamakali mengkuti kegiatan ujian online, sehingga aplikasi ini adalah hal yang baru bagi mereka.

\section{Kondisi Sarana Pendukung}

Kondisi sumber daya pendukung dalam pelaksanaan ujian online menurut para responden masih kurang memadai, khususnya mengenai wifi kampus yang terkadang kurang stabil sehingga petugas perlu menyediakan jaringan internet portable untuk mendukung pelaksanaan ujian online. Selain itu, petugas juga perlu memeriksa kondisi perangkat komputer yang akan digunakan sebelum pelaksanaan ujian online.

\section{Tingkat Kepuasan Responden terhadap Implementasi Ujian Online}

Tingkat kepuasan mahasiswa terhadap implementasi ujian online menggunakan kuis LMS Moodle adalah sebagai berikut:

Bagan 1. Kualitas tampilan halaman ujian online

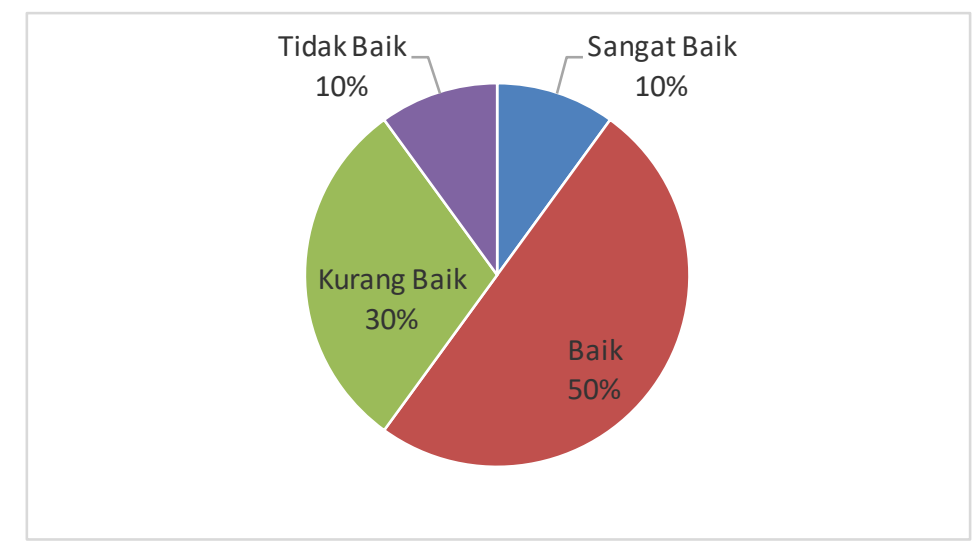

Bagan 2. Tingkat kesederhanaan fitur-fitur ujian online

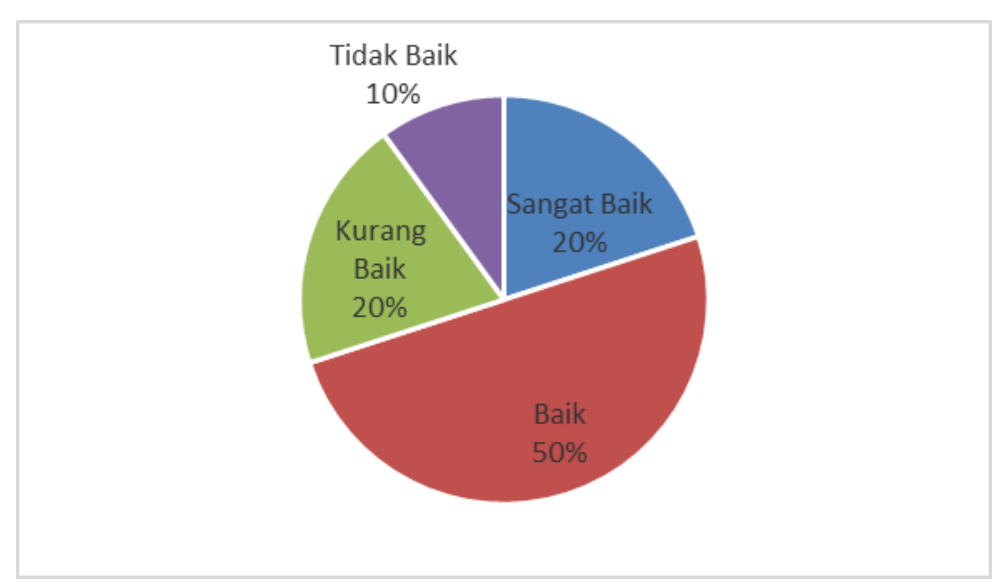


Hamdan Husein Batubara, Studi Implementasi Ujian Online...

Bagan 3. Tingkat kemudahan penggunaan halaman ujian online

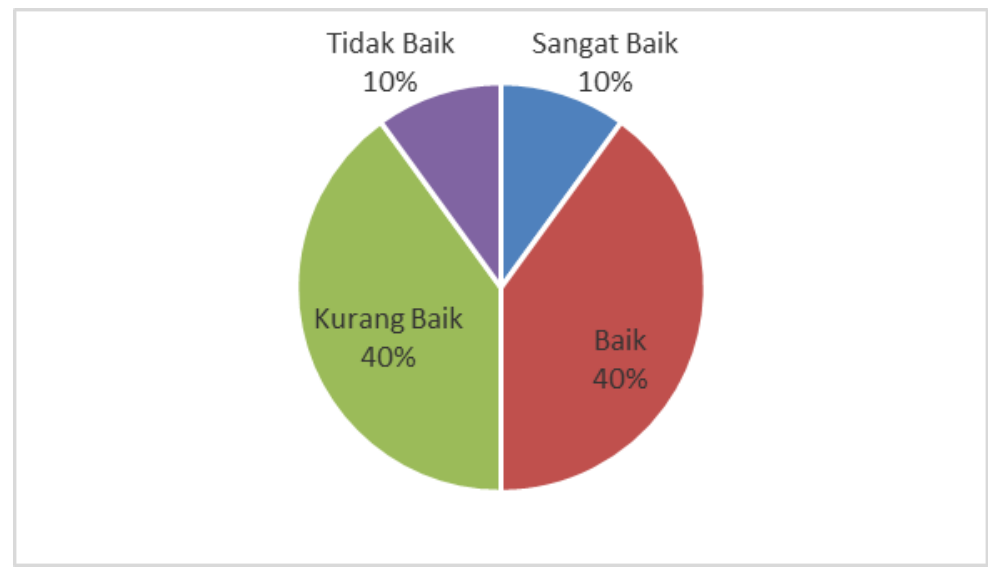

Bagan 4. Tingkat efisiensi waktu pelaksanaan ujian online

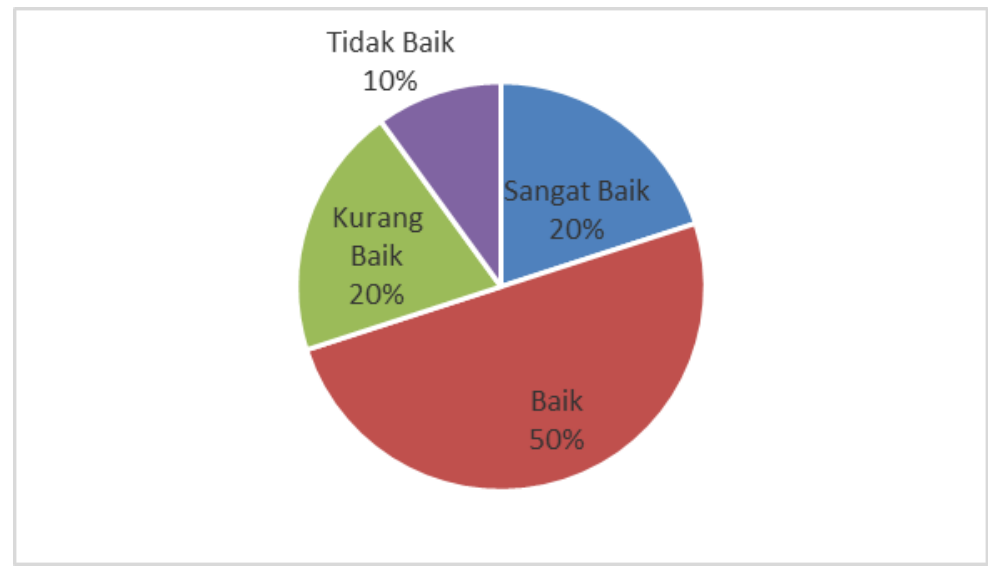


Bagan 5. Nilai manfaat pelaksaan ujian online

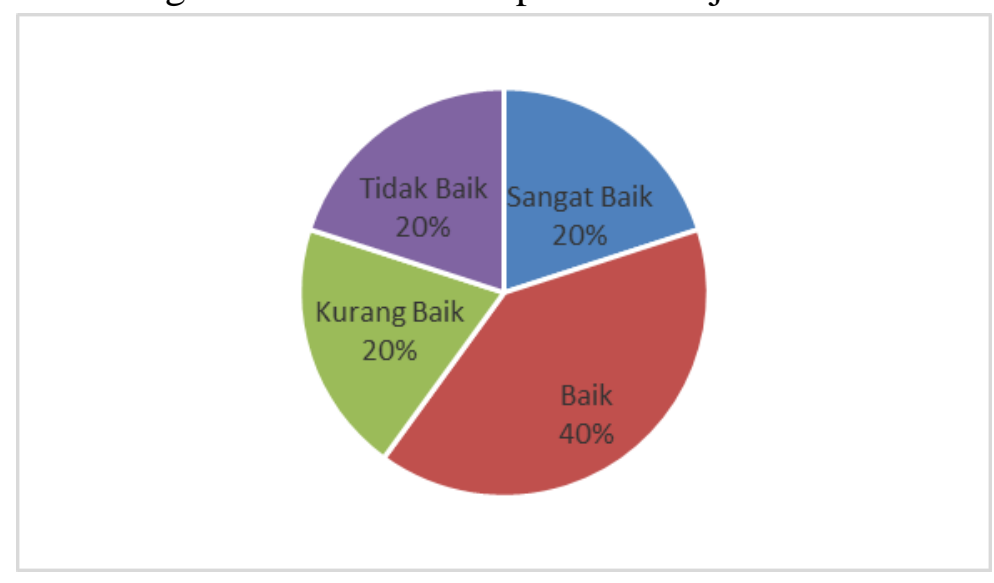

Bagan 6. Dukungan responden terhadap pelaksaan ujian online

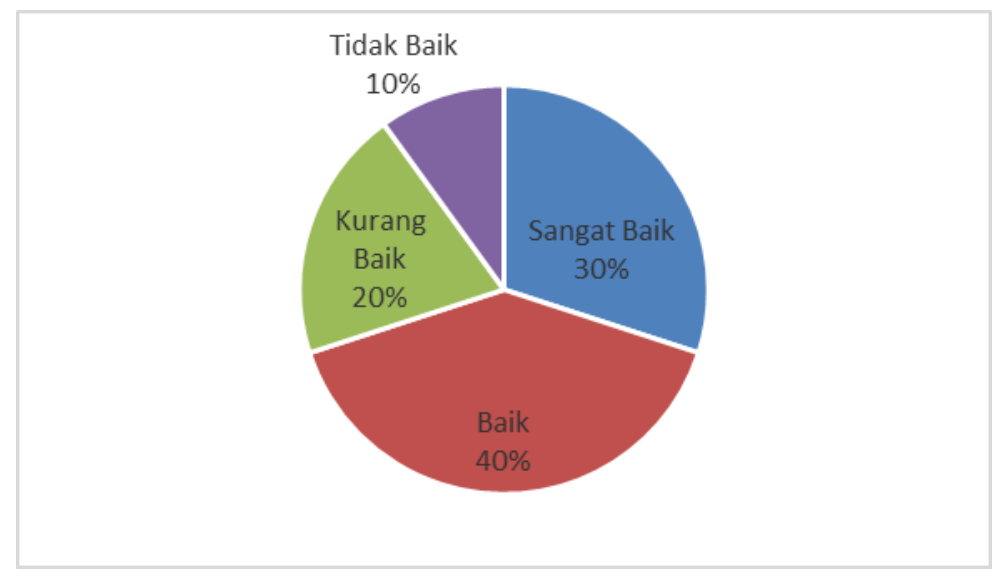

Akumulasi persentasi tanggapan seluruh responden berdasarkan kategorisasi pilihan jawaban mereka adalah sebagai berikut.

Bagan 7. Akumulasi tanggapan seluruh responden

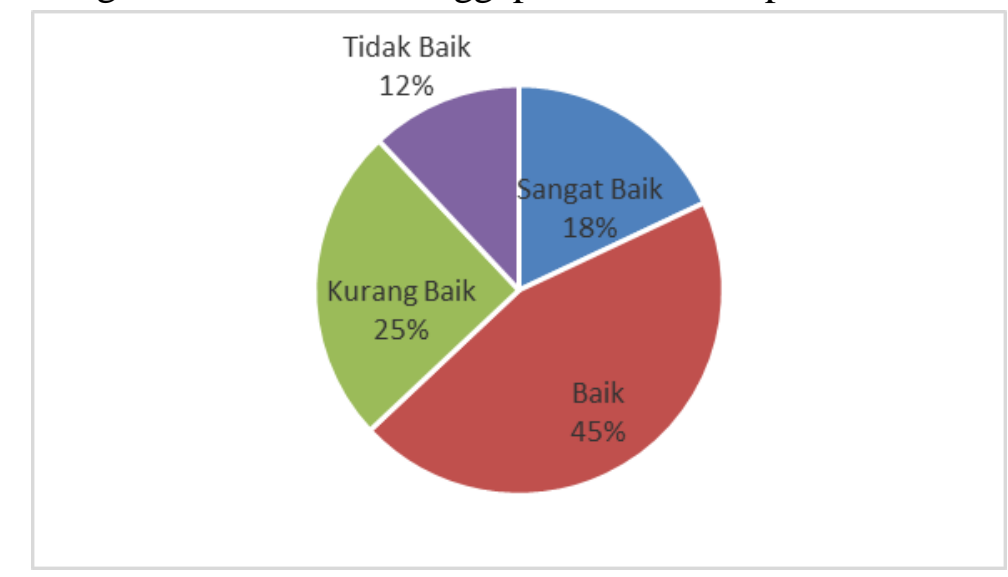

Berdasarkan data di atas, implementasi ujian online menggunakan LMS Moodle pada program studi Pendidikan Guru Madrasah Ibtidaiyah Uniska berada dalam kategori baik. Adapun komentar responden tentang beberapa hal-hal yang perlu ditingkatkan dalam 
implementasi ujian online ini adalah: jumlah komputer, kualitas jaringan internet, dan penguatan terhadap sosialisasi pelaksanaan dan tata tertib pelaksanaan ujian online.

Beberapa temuan dalam penelitian ini menjadi bahan masukan dalam peningkatan kualitas penyelenggaraan ujian online. Adapun beberapa alternatif penyelesaian masalahmasalah yang ditemukan dalam penelitian ini antara lain, Purbo dalam kutipan Darmawan (2014) yang menghimbau agar pendidik bersikap transparan dalam menyampaikan petunjuk pelaksanaan ujian online. Seperti petunjuk pengerjaan soal, jumlah soal dan batas waktu pengerjaan soal, dan peralatan yang dibutuhkan dalam pelaksanaan ujian online.

Darmawan (2014) juga mengungkapkan tentang pentingnya menganalisis berbagai faktor pendukung penggunaan e-learning dalam kegiatan perencanaan. Seperti: analisis kebutuhan dan tujuan pelaksanaan ujian online, kelengkapan infrastruktur pendukung seperti telepon dan listrik, fasilitas jaringan internet (internet infrastructure) dan koneksi internet (internet connections), ketersediaan software yang akan digunakan, kemampuan orang yang akan menggunakannya, dan kebijakan dan peraturan tentang standar pelaksanaan ujian online (Darmawan, 2014: 40).

Adapun beberapa manfaat yang ditemukan dari penggunaan LMS Moodle sebagai media ujian online adalah: 1) membantu guru dalam menyimpan soal-soal yang telah terverifikasi pada bank soal, 2) membantu guru dalam membuat kuis dalam waktu yang singkat dengan menggunakan soal-soal yang telah didokumentasikan pada bank soal, 3) membantu guru dalam menganalisis nilai peserta didik dan melaporkannya kepada peserta didik dalam waktu yang cepat, dan 4) pelaksanaan ujian online dengan peraturan yang terperinci dan pembatasan akses diharapkan dapat meminimalisir tindakan kecurangan dalam pelaksanaan ujian online. Misalnya membatasi waktu tersedianya kuis, waktu pengerjaan kuis, dan pengacakan urutan soal secara otomatis pada setiap kali diakses oleh peserta didik.

Manfaat lain dari pelaksaan ujian online juga adalah dapat membiasakan pelajar dalam menggunakan perangkat teknologi informasi dan komunikasi pada bidang Pendidikan sehingga pada kesempatan lain mereka tidak kaget lagi dalam mengikuti tes yang dilaksanakan secara online, misalnya tes CPNS dan tes TOEFL IBT..

\section{SIMPULAN}

Adapun beberapa hal yang menjadi kesimpulan penelitian ini adalah sebagai berikut:

1. Tampilan halaman ujian online dengan menggunakan LMS Moodle menarik dan mudah dimengerti.

2. Prosedur implementasi ujian online menggunakan LMS Moodle terdiri dari: mempersiapkan kisi-kisi dan item soal yang akan diujikan, membuat kategori soal, membuat dan 
mengunggah soal pada bank soal, membuat kategori nilai, menambahkan fitur kuis, melaksanakan ujian online, mengoreksi nilai, dan mengunduh nilai.

3. Tingkat kepuasan responden pada pelaksanaan ujian online berada pada kategori baik sebesar $45 \%$, sangat baik $18 \%$, kurang baik $25 \%$, dan tidak baik $12 \%$.

4. Hal-hal yang perlu diperhatikan sebelum pelaksanaan ujian online adalah: kondisi jaringan internet, jumlah komputer yang siap pakai, dan sosialisasi standar penyelenggaraan ujian online.

5. LMS Moodle direkomendasikan sebagai salah satu aplikasi pelaksanaan ujian online.

\section{DAFTAR PUSTAKA}

Darmawan, D. (2014). Pengembangan E-Learning: Teori dan Desain. Bandung: PT. Remaja Rosda Karya.

Emzir. (2008). Metodologi Penelitian Pendidikan_Kuantitatif \& Kualitatif (Korelasional, Eksperimen, Ex Post Facto, Etnografi, Grounded Theory, Action Research. Jakarta: Rajagrafindo Persada.

Fauzi, M. R. (2017). Penggunaan Google Form sebagai Alat Evaluasi Pembelajaran pada Mata Pelajaran Bahasa Indonesia, Universitas Pendidikan Indonesia. http://repository.upi.edu. [23-02-2017].

Kompas. (2008). Moodle: Portal E-Learning. Kompas Tekno. http://tekno.kompas.com/read/2008/07/31/0719116/moodle.portal.e-learning. [08-052017] .

Prismanata, Y. (2016). E-Learning (Bagian 8): Membuat Quiz dan Import Soal Secara Cepat di Moodle. http://www.eduprisma.web.id /2016/12/e-learning-bagian-8-membuat-quizdan.html. [12-05-2017]

Siregar, S. (2013). Metode Penelitian Kuantitatif dilengkapi dengan perbandingan Perhitungan Manual \& SPSS. Jakarta: Kencana.

Tim Direktorat Pembinaan Sekolah Dasar Kemdikbud. (2016). Panduan Penilaian untuk Sekolah Dasar. Jakarta: Kemdikbud. 